\title{
Breakthrough Treatment of Rheumatoid Arthritis In the Light of Nucleopathy
}

\author{
Shahid Sheikh* \\ NIDS Treatment \& Research Center, Lahore, Pakistan \\ Submission: July 15, 2018; Published: July 24, 2018 \\ *Corresponding author: Shahid Hussain Sheikh, Chairman, NIDS Treatment \& Research Center Trust, Lahore, Pakistan, Tel: 92-300-481-6677; \\ Email: Profdrshahid@gmail.com
}

Abstract

Rheumatoid Arthritis is a chronic disease in almost in every community across the planet with no cure. Patients suffering from this ailment live a very disturbed and painful quality of life using a variety of steroidal remedies for symptomatic temporary relief. Weight gain, and other prominent derogatory health conditions prevail swiftly that carry a social and financial burden on the family.

\section{Introduction}

Conventional allopathy has no solution but the symptomatic transitory relief. Interestingly, many physicians cater the remedial cocktail to RA Patients focusing on the pain relief. Therefore, to decrease the frequency and inconvenience of the symptomatology. It is very logical lead to start tracing the involvement of the nervous system right from the effected tissues involved in this ailment and track the possible neo-pathogenesis of the RA.

Indeed, it's the branch of peripheral nerve that distribute the supply of Neuro network to link the end tissues with the controlling neurons. The Nanopathophysiology of the controlling neurons are never taken into an account for a possible involvement in the systems malfunctioning. Long behold, as we tracked this novel phenomenon and found a new positive revelation. The controlling neurons nuclei overwhelmed with the Neuro-invasive viral genomic proliferation, in turn, incapacitating the neuronal homeostasis. Therefore, instigation of the rheumatoid arthritis pain comes into play causing RA $[1,2]$.

\section{Material \& Methods}

Patients with age ranging from 60 years to 72 years suffering from RA for over 3 years were tested for the increase serum antibodies against proliferating Neuro-invasive viral genomes, Sub-Nucleusly. Patients were found carrying positive antibodies against Cytomegalo Virus CMV beyond normal established limits. This substantiated the overwhelming viral genomic burden in the nuclei of the controlling neurons that had disrupted the normal functional integrity of the area involved in pain. Patients were given the antiviral infusion therapy with the supportive medicine to establish the mainstay of the treatment, twice a day for 15 days. Infusions consisted of Dextrose 5\% / N.S 0.9\%, 500 $\mathrm{ml}$ with Ganciclovir $250 \mathrm{mg}$, Dexamethasone $1 \mathrm{ml}$, Vitamin B12, Ranitidine $2 \mathrm{ml}$ and Antihistamine $2 \mathrm{ml}$. Gravitate/Maxolon were used on a standby basis to retard the possibilities of nausea and vomiting. All patients responded well to the antiviral infusion therapy relieving the RA symptomatology after 1st five days of the treatment. Minor headaches and sporadic and transient body pains were reported that were rectified with additional use of analgesics $[3,4]$.

\section{Results}

Patients well tolerated the antiviral infusion therapy without any remarkable event. All patients reported increasing relief of the arthritic pain after $5^{\text {th }}$ day of the antiviral infusion therapy. Patients were tested to against Arthritic symptoms after the $15^{\text {th }}$ day into the treatment. They were all found pleasantly surprised with no more Arthritic Pains and carry out normal movements and walk without support.

\section{Conclusion}

Once the sub-nuclei CMV genomic proliferation deteriorated via its appropriate antiviral infusion therapy, the nuclei regained their control over their respective cell body to reinstitute homeostasis. This substantiated the actual cure of this disease. A wonderful step to return the quality of life to the mankind.

\section{Acknowledgement}

Our organization is grateful for their commitment dedication and empathy for the patient care 
And providing personal support to patient, treatment protocols in achieving prognoses positive.

i. Dr. Muhammad Nawaz Malik, M.D. (Alt.Med)

ii. Dr. Uroosa Awan, MBBS

iii. Mrs. Surriya Sarfraz, RN.

iv. Ms. Maria Sharif, RN.

v. Ms. Zamiha Abdul Wahid, RN

\section{References}

1. Wagner EK (1999) Herpes Simplex Virus-Molecular Biology. In "Encyclopedia of Virology $2^{\text {nd }}$ edition." (RG Webster and A Granoff, editions) pp. 686-697 Academic Press, London, USA.
2. Shahid Hussain Sheikh, Shakeel Waqar, Saima Chaudhary (2014) Neuro Invasive Viruses the Silent and the Slow Killer. IOSR Journal of Dental and Medical Sciences 13(3): 69-71

3. Wagner EK, Garcia Ramirez JJ, Stingley SW, Aguilar JS, Buehler L, et al. (2002) Practical Approaches To Long Oligonucleotide-Based DNA Microarray: Lessons From Herpes Viruses. Prog Nucleic Acid Res Mol Biol 71: 445-491.

4. Shahid Hussain Sheikh (2012) Breakthrough Treatment of Hypertension, Hypertension's "Syndrome X" is now Re-defined. IOSR Journal of Dental and Medical Sciences 1(5): 33-38

\section{Your next submission with Juniper Publishers will reach you the below assets}

- Quality Editorial service

- Swift Peer Review

- Reprints availability

- E-prints Service

- Manuscript Podcast for convenient understanding

- Global attainment for your research

- Manuscript accessibility in different formats

( Pdf, E-pub, Full Text, Audio)

- Unceasing customer service

Track the below URL for one-step submission https://juniperpublishers.com/online-submission.php 